\title{
Parameters of lightning activity in the tropical cyclones at the stage of maximum development in August 2016
}

\author{
Svetlana Shabaganova ${ }^{1 *}$, Lena Tarabukina ${ }^{2}$, and Vladimir Kozlov ${ }^{2}$ \\ ${ }^{1}$ Polytechnic Institute (branch) M.K. Ammosov North-Eastern Federal University, Mirny, Russia \\ ${ }^{2}$ Institute of Cosmophysical Research and Aeronomy, Siberian Branch of the Russian Academy of \\ Sciences, Yakutsk, Russia
}

\begin{abstract}
This article discusses the parameters of thunderstorm activity in the structure of tropical cyclones that had an impact on the Russian Far East in August 2016. The study shows in detail the change in the cloud mass and describes its structure during the lifetime of the most powerful tropical cyclone Lionrock (2016). It is shown that the density distribution of lightning discharges in the range of tropical cyclones (up to $1000 \mathrm{~km}$ ), reaching the typhoon stage, is characterized by two local maxima. The distribution density of lightning discharges in the range of tropical cyclones that have reached a strong tropical storm is characterized by one maximum. The lifetime of thunderstorm cells that stand out is 40-50 minutes in average. Before the typhoon stage, the area of thunderstorm cells increased, and then, the number of cells as well as the intensity of discharges in the cell increased, but their lifetime and area decreased.
\end{abstract}

\section{Introduction}

The economy of any state significantly depends on weather conditions. Extreme sectors, such as floods and hurricanes, have a significant impact on various sectors of the economy. One of the reasons for the occurrence of such dangerous phenomena is tropical cyclones, which are almost always accompanied by powerful thunderstorms. At the same time, meteorological parameters, together with the spatio-temporal characteristics of thunderstorm areas identified in the structure of a tropical cyclone, make it possible to predict the degree of danger of a natural phenomenon.

In August 2016, 5 tropical cyclones, which reached the territory of Russia at the stage of a collapsing cyclone, had the greatest influence on the Far East. Of these, tropical cyclones Lionrock and Mindulle reached the typhoon stage with a wind speed of about $36 \mathrm{~m} / \mathrm{s}$. The maximum stage of development of tropical cyclones Omais, Conson and Chanthu is a strong tropical storm.

\section{Research Methods}

\footnotetext{
*Corresponding author: ssnik@inbox.ru
} 
In the Far Eastern region of the country, data obtained by means of the international global network WWLLN are used to monitor thunderstorm activity [1-3]. WWLLN is a system that accurately records the electromagnetic pulse generated by lightning discharges in the kHz-range. In [4], an accuracy assessment showed that the reliability of WWLLN measurement data is higher than the probability of a false diagnosis when comparing with tolerances of 50,75 and $100 \mathrm{~km}$. Reliability indicators are respectively $0.65,0.77$ and 0.82 .

In this paper, we studied thunderstorm regions identified in the structure of a tropical cyclone based on an analysis of data from the WWLLN thunderstorm registration system. One of the receiving points of this scientific network for registering lightning discharges is located in Yakutsk. In [5], it was proposed to transform the data of the lightning location system (WWLLN) into a grid with a node spacing of $8 \mathrm{~km}$. The study analyzes lightning discharges received by the WWLLN registration system in the territory of $10^{\circ}-35^{\circ} \mathrm{N}, 125^{\circ}$ $145^{\circ} \mathrm{E}$ with a grid node spacing of $2.5 \mathrm{~km}$ in August 2016.

For analysis, we used the methods of cluster analysis implemented in the software package. Clustering was carried out similarly to the method presented in [6]. The data from http://agora.ex.nii.ac.jp/digital-typhoon and https://worldview.earthdata.nasa.gov have been also used in this study.

\section{Experimental data and results}

The largest in August 2016 was the impact of the tropical cyclone Lionrock. Figure 1 according to https://worldview.earthdata.nasa.gov in the $20^{\circ} \times 20^{\circ}$ region. According to http://agora.ex.nii.ac.jp/digital-typhoon, it originated on August 16, 2016 with a tropical disturbance center of $26.4^{\circ} \mathrm{N}$ and $159.1^{\circ} \mathrm{E}$ (fig.1.1). An increase in wind speed in the region of tropical disturbance has not been observed yet; it remains small. In the region of disturbance formation, an increase in the amount and thickness of cloudiness occurs, which is accompanied by an increase in convection in the zone of cloud bands.

The transition to the stage of tropical depression occurred on August 21, 2016 (fig. 1.2). The center is $29.2^{\circ} \mathrm{N}$ and $133.3^{\circ} \mathrm{E}$. At the same time, Typhoon Mindulle, which is in the stage of a tropical storm, is recorded at a wind speed of $25 \mathrm{~m} / \mathrm{s}$, its center is to the right with coordinates $28^{\circ} \mathrm{N}$ and $140.6^{\circ} \mathrm{E}$. At the same time, a certain order in the distribution of clouds is found in the cloud massif. It manifests itself in the acquisition of a certain specific form and in the appearance, more often to the west of it, of thin ridges of cumulus clouds. The appearance of cirrus clouds usually serves as a sign of rapid deepening of the emerging tropical cyclone. Cirrus clouds form in the shape of stripes, which, as a rule, break off along the edges of the central cloud vortex, which has now become the main one. Separate spiralshaped strips of clouds depart from the cloud massif [7].

On August 22, 2016, the center of a tropical cyclone in a stage of a tropical storm is $28.2^{\circ} \mathrm{N}$ and $134^{\circ} \mathrm{E}$ (fig. 1.3). The wind speed is about $23 \mathrm{~m} / \mathrm{s}$.

On August 24, 2016, the center of the tropical cyclone is $25.8^{\circ} \mathrm{N}$ and $133.3^{\circ} \mathrm{E}$ (fig. 1.4 ). Wind speed is about $36 \mathrm{~m} / \mathrm{s}$ at the surface. The structure of the cloud system of this tropical cyclone shows that it reaches the maturity stage - the typhoon stage. The image shows a dense, round array of continuous cloudiness, spiral-like clouds of cloudiness depart from it counterclockwise (the image was obtained in the northern hemisphere). Cloud bands are made up of thick cumulonimbus clouds formed into cells. The main cloud massif typhoon Lionrock is homogeneous in its structure.

In [8], 7 typhoons formed from July to November 2012-2013 were considered. It was shown that in all the typhoons under consideration in the central region, on the very day preceding the onset of maximum development, structures were observed that are parts of annular or spiral formations of a mesometeorological scale that can be associated with the presence of a cloudy wall of the typhoon eye. In [8], typhoons Haiting, 07/16/2005 and 
Sanba, 09/13/2012. Characteristic elements of the typhoon structure were observed spiral bands coinciding with cloudy ones were considered. Ring structures were fully manifested on the day of maximum development, and then began to collapse. It is shown that by the distribution of lightning it is possible to evaluate the position of the center of the typhoon and the speed of its movement, as well as obtain estimates of the geometric characteristics of the eye wall, which are given in storm reports on hurricanes and typhoons.

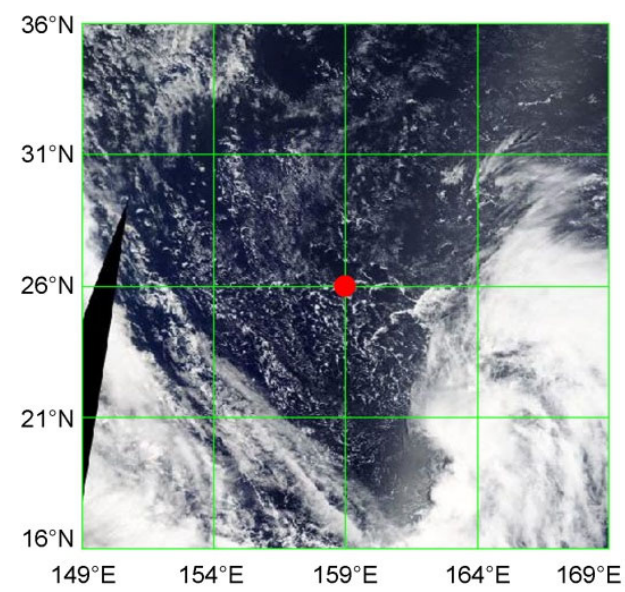

1).

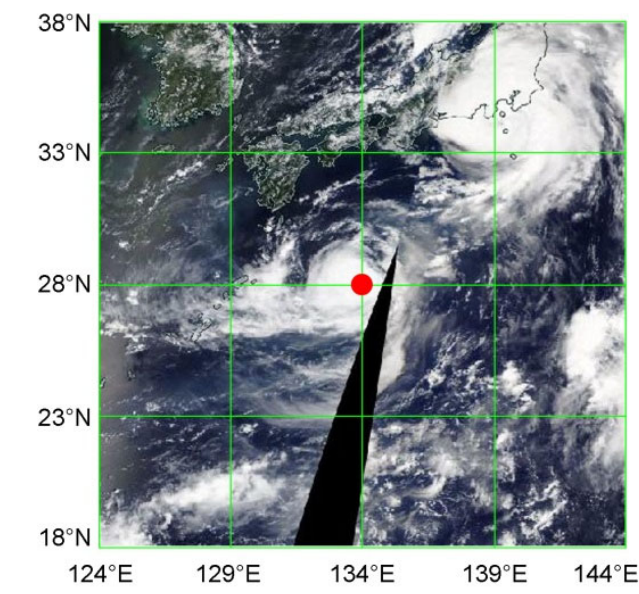
3).

Fig. 1. The stages of development of a tropical cyclone on August 16, 2016 (the center of the tropical cyclone is marked with a red dot).

Approaching the center of the cyclone, cloud stripes go under the cover of cirrus clouds. The average width of the stripes is $200-300 \mathrm{~km}$, and in some cases more. Tropical storms most often have two cloud bands: one of them is located in the southwestern part of the tropical cyclone, and the second in the northeast [9].

During the formation of a typhoon (at the stages of a tropical depression and even a tropical storm), points corresponding to lightning discharges are distributed relatively randomly. On the day of maximum development on August 24-25, 2016, spiral bands coinciding with the boundaries of the cloud were also observed in the field of the 
distribution of lightning discharge density. Figure 2 shows the lightning fields in the typhoon Lionrock on August 25, 2016, the red line shows the movement of the center of the tropical cyclone for the entire period of its existence.

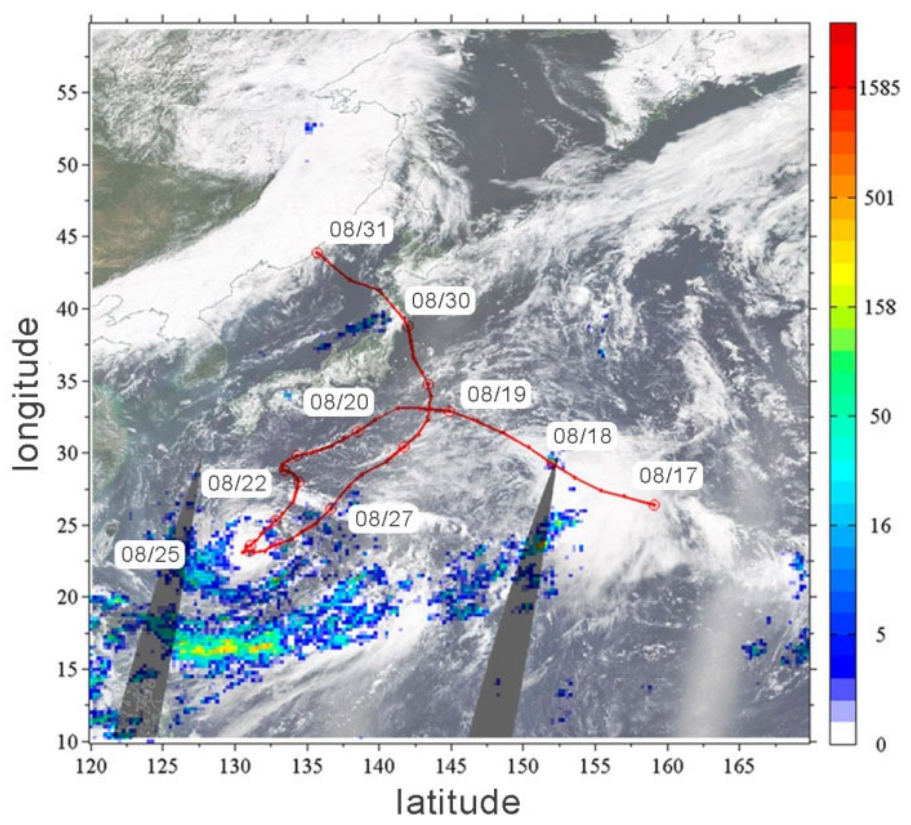

Fig. 2. The spatial density of lightning discharges in typhoon Lionrock on August 25th.

Above the seas and oceans, there is no influence of orography. The spatiotemporal distribution of lightning discharges in thunderclouds is controlled by thermodynamic (1000 $\mathrm{km}$ scale) and mesometeorological $(10-200 \mathrm{~km})$ structures [10]. To select the area for analysis, the size of the typhoon area should be considered. In [11], registration was carried out within a radius of $500 \mathrm{~km}$.

According to the results of these studies, the distribution density of lightning discharges in the range of tropical cyclones (up to $1000 \mathrm{~km}$ ) that have reached the typhoon stage is characterized by two local maxima. The distribution density of lightning discharges in the range of tropical cyclones that have reached a strong tropical storm is characterized by one maximum.

In the spatial distribution of the density of lightning discharges in a separate cell of the Lionrock typhoon, the maximum is observed in the inner part of the spiral bands up to 100 $\mathrm{km}$ from the center of the typhoon, the minimum in the inner strip in a radius of 100-250 $\mathrm{km}$ and the secondary maximum in the outer bands from 260 to $1000 \mathrm{~km}$, as in [12].

A more detailed study of the cloud structures of tropical cyclones in the typhoon stage using the clustering of lightning discharges revealed that cloudiness has a cellular structure and the lifetime of the selected cells is 41 minutes in average. This time coincides with the median $(41 \mathrm{~min})$, with a mode equal to $50 \mathrm{~min}$. The average cell area reaches maximum values at the typhoon stage.

The analysis of the shape of the cells showed that the maximum eccentricity of the ellipse describing the shape of the cell, up to 0.8 , corresponds to the maximum wind value of $43 \mathrm{~m} / \mathrm{s}$, and is observed in short-lived cells of a thundercloud within the radius of action of tropical cyclones. At the stage of a tropical storm, the area of each cell monotonously 
increased taking into account the diurnal course of the density of lightning discharge flux, and then, when entering the typhoon stage, the number of cells increased, the intensity of lightning discharges in each cell increased, and their lifetime and area decreased.

\section{Conclusion}

As a result of this work, the possibility of using the WWLLN world lightning location registration system to study the spatio-temporal characteristics of thunderstorm activity accompanying tropical cyclones in August 2016 was shown. This study made it possible to track and describe the change in the cloud massif, as well as to identify variations in the parameters of thunderstorm activity during vortex phenomena in the atmosphere.

This work was carried out with the partial financial support of the Russian Foundation for Basic Research 18-45-140028 r_a, 18-35-00215 and II.16.2.1. (state registration number AAAA-A17117021450059-3).

\section{References}

1. L.D. Tarabukina, V.I. Kozlov, R.R. Karimov, V.A. Mullayarov, Meteorology and hydrology, 2, 20-29 (2017)

2. G.I. Druzhin, Y.B. Bashkuev, I.B. Naguslaeva, N.V. Cherneva, B.M. Shevtsov, Optics of the atmosphere and ocean, Physics of the atmosphere, 416-419 (2016)

3. A.N. Melnikov, D.V.Sannikov, N.V. Cherneva, G.I. Druzhin, Transactions of a regional scientific and technical conference, 2, 186-190 (2008)

4. I.M. Gubenko, K.G. Rubinstein, Meteorology and hydrology, 5, 40-53 (2014)

5. S.N. Stevenson, K.L. Corbosiero, M. DeMaria, J.L. Vigh, J. Weather and Forecasting, 33, 1, 23-36 (2018)

6. S.N. Shabaganova, Vestnik of NEFU, 1, 69, 58-69, (2019)

7. M.A. German, Satellite Meteorology: The Basics of Space Research Methods in Meteorology (Gidrometeoizdat, Leningrad, 1975)

8. M.S. Permyakov, E.Y. Potalova, B.M. Shevtsov, N.V. Cherneva, R.H. Holzworth, Atmospheric and Oceanic Optics, 28, 6, 585-590 (2015)

9. C. Price, M. Asfur, Y. Yair, Nature Geoscience, 2, 5, 329-332 (2009)

10. M.S. Permyakov, E.U. Potalova, A.N. Droga, B.M. Shevtsov, Research of the Earth from space, 4, 59-67 (2017)

11. Wang Fang, Qie Xiushu, Liu Dongxia, J. Meteor. Res., 30, 1, 117-127 (2016)

12. L.X. Pan, X.S. Qie, D.F. Wang, Adv. Atmos. Sci., 31, 3, 581-592 (2014) 